\title{
Sustainable Development in Mountainous Areas: Relimitation of Mountain Areas in Giresun Province and A Socio-Economic Analysis*
}

\author{
Dağglı Alanlarda Sürdürülebilir Kalkınma: Giresun İli Dağlık Alanlarının Sınırlandırılması \\ ve Sosyo-Ekonomik Özellikleriyle Analizi
}

\author{
Yusuf KIZILKAN ${ }^{1} \mathbb{D}$, Saliha KODAY $^{1}$ (D) \\ ${ }^{1}$ Ataturk University, Faculty of Letters, Department of Geography, Erzurum, Turkey
}

ORCID: Y.K. 0000-0001-9815-8129; S.K. 0000-0003-2515-4287

\begin{abstract}
The integration of sustainability to the concept of development and the sustainable development goals set by the United Nations added another dimension to the relationship between human and environment. The Brundtland Report and Agenda 21 report published in 1987 and 1992, respectively, diversified the mountainous area approaches and they have become a research subject for sustainability research. Studying developmental aspects of sustainability approaches towards mountainous areas and determining their limits have posed challenges since the beginning. Recently, these impediments are overcome by various Geographic Information Systems and criteria for mountainous area relimitations based on environmental and topographic characteristics. However, socio-economic assessments for the mountainous area relimitations are yet to be performed. This article highlights the importance of international and national scale in, several relimitation projects and analysis of Giresun's mountainous areas focusing on topographical and the socioeconomic characteristics. A three-step approach has been adopted for socio-economic analysis of mountainous areas. The first step is the introduction of the physical integrity of the mountainous areas and the natural environmental conditions. The second is to determine the boundaries of mountainous areas and zones affected by mountainous areas in social and economic terms by adhering to natural conditions. Third, the socio-economic analysis of the mountainous areas in Giresun Province through 11 criteria. An assessment proposal based on socio-economic characteristics regarding human-nature interactions in mountainous areas has been presented, as well. The diversity of aspects that affect the sustainability of mountainous areas is explained with practical examples.
\end{abstract}

Keywords: Mountainous Area, Socio-Economic Analysis, Giresun Province

*This article is part of the doctoral dissertation on Sustainable Development in Mountainous Areas of Giresun, which is prepared by Yusuf Kızılkan and conducted under the supervision of Saliha Koday, with several updated and additional topics.

Submitted/Başvuru: 30.12.2020 • Revision Requested/Revizyon Talebi: 03.04.2021 • Last Revision Received Son Revizyon: 29.04 .2021 • Accepted/Kabul: 11.05.2021 • Published Online/Online Yayın: 18.08 .2021

Corresponding author/Sorumlu yazar: Yusuf KIZILKAN / yusuf.kizilkan@atauni.edu.tr

Citation/Atıf: Kizilkan, Y., \& Koday, S. (2021). Sustainable development in mountainous areas: relimitation of mountain areas in Giresun Province and a socioeconomic analysis. Cografya Dergisi. Advance online publication https://doi.org/10.26650/JGEOG2021-850275 


\section{INTRODUCTION}

The scholarship on sustainable development has made remarkable progress during the second half 20th century. The concept was first introduced at the Stockholm Conference, with the report titled "The Limits to Growth" published by the Club of Rome. Though this report, special committees were created to investigate five major global concerns trends such as expediting industrialization, rapid population growth, widespread malnutrition, depletion of non-renewable resources, and degraded environment. After these initiatives, the concept of sustainable development became more widespread under the leadership of the United Nations and numerous non-governmental organizations. Sustainable development emerged from the necessity to introduce the relationship between economic development and environmental changes with a conservation approach and taking a leading role as a result of rapid technological development and advancement. (UNCED, 1972: 1; Botkin, Elmandjra and Malitza, 1979: 1-7).

Despite having various definitions, comprehensive sustainable development, which was proliferated and adopted around the world after the report named "Our Common Future" prepared by the World Commission on Environment and Development (WCED) in 1987, is usually attributed to the Brundtland Report which defined the concept as "we must ensure that development meets the current needs without sacrificing the ability to meet the needs of future generations." Sustainable development is not a state of accord with current conditions, but a process of change in which resource utilization is primarily taken into account, the direction of investments, technological development, and institutional change is made consistent with both future and current needs (WCED, 1987: 15; WCED, 1987: 43; Fisunoğlu, 1997: 13; Hulse, 2007: 15; Uzun, 2014: 47).

Sustainable development principles and methods for mountainous areas were formulated with the Brundtland Report and the Agenda 21 Report published after the United Nations Environment Conference in 1987 and 1992, respectively. Mountainous areas play a vital role for sustainability in humannature interaction thanks to their resourceful capacity. As the water towers of the world, mountains shall have a fundamental role in providing fresh water to agriculture and irrigation, biological diversity, industry-driven development, food safety, poverty reduction and hence the political stability. Increasing mountainous urbanization in direct proportion to the increasing number of people causes additional pressure on scarce resources such as biodiversity, climate change, deterioration in land-use patterns and water (Mountain Agenda, 2002: 4; Uzun and Somuncu, 2013: 1; Bayar and Karabacak, 2020: 2). Sustainable development in mountainous areas emerged in the process of eliminating these difficulties and transmission of these resources to future generations. The significance of mountainous areas for countries, grasped increasing attention especially after the United Nations Conference on Environment and Development (UNCED) in 1992 in Rio de Janeiro as thoughts on the unique value of mountainous areas have become widely accepted (Price and Kohler, 2013: 333; Kohler et al., 2012: 7; Godde, Price and Zimmermann, 2000: 1; Price, 2004: 1). In the conference on environment and development held in 1992, various policies regarding the protection and management of mountain areas and opinions on how mountainous area development should be were examined under the title of Managing a Sensitive Ecosystem: Sustainable Mountain Development in the 13th chapter of Agenda 21. According to the principles set out in Agenda 21, there are two program areas in this section to further elaborate the fragile ecosystem problems for all mountains of the world. These are:

a. To generate and strengthen knowledge about the ecology and sustainable development of mountain ecosystems;

b. The promotion of integrated water basin development and alternative subsistence opportunities (UNCED, 1992: 119).

The aims and objectives of the sustainable development phenomenon in mountainous areas are determined with Agenda 21 articles. The accumulation of knowledge has continued from past to present according to these goals and objectives, with studies that include both socio-economic and natural environmental characteristics. The Agenda 21 report, in which the foundations of sustainable development in mountain areas were laid, highlights the importance of water availability in mountain areas, biodiversity, protected areas, land use potential and management of natural disasters in the transfer of sensitive ecosystems and natural resource richness to the future. Therefore, land use systems developed in mountainous areas emphasize the role of natural and cultural manpower and provide resource diversification ( $\mathrm{Li}$ et al. 2018). Economic living standards in mountains and mountainous areas, tourism opportunities, health and education services, political decisions that respect human rights are reflected in the human development index and human security index in general. Mountain areas, together with the geomorphological units it contains, regional and transboundary cooperation, food production areas, forest areas, protection of land areas and the living standards of the population in 
mountainous areas are analyzed in a holistic manner in several scientific studies (Somuncu, 2002: 187; Gönençgil, 2009: 119; Akten and Gül, 2014: 130; Messerli, 2012: 60; Sati, 2005).

The importance of geographical studies to the wider mountain research is sometimes obscured by definition problems, different natural environments and socio-economic traditions. Geologists generally admit that they set their boundaries within the mountain environment in their studies on natural environment characteristics. In contrast, human geographers make narrow comments on descriptive statements about places in a mountainous area, especially in many studies of agricultural change or demography. The existence of mountainous areas that differ from each other in terms of quality lead to different definitions (Funnell and Price, 2003: 183). In recent years, there has been noteworthy neglect in scientific studies of mountains to introduce a definition of mountains or mountainous areas. Although this is somewhat justified by the statement that mountains are defined by local perceptions, there is an insufficiency in providing an overview of the world mountainous areas in a geographical context. Country-specific and regional topography changes and fractionation on the world surface caused difficulties in defining mountainous areas clearly according to the effect of geographical factors. Roderick Peattie proposes several subjective criteria for describing mountains in his seminal Mountain Geography (1936): “(1) mountains must be impressive, (2) enter the imagination of people living in their shadow, and (3) they must be individual". According to Körner (2003) and Löve (1970), the word "Alp" is of European origin and the terms "alp" or "allo" with roots dating back to preRoman times mean "mountain" in Turkish. In Europe, New Zealand and Japan, this term is generally implied to all mountainous areas, which may include valleys, forests and pastures (Peattie, 1936: 4; Soffer, 1982: 392; Funnell and Price, 2003: 183; Price, 2013: 3). In another definition, mountainous areas can be defined as high areas with large elevation variances within short distances, generally divided by narrow and deep valleys, and where slope inclines are high and continuous (Hoşgören, 2011: 62). Furthermore, mountains are defined as higher units separated from lower areas such as plain and plateaus by inclined slopes where erosional processes are observed. As the mountainous areas comprise single peak or mountain ranges in which areas with low slopes such as plain and plateau can be found, with a certain elevation difference with their surroundings (Gönençgil, 2009: 17; Gönençgil, 1999).

Holistic approaches towards mountainous areas have been developed upon the progress made through recent definitions of relimitation of mountainous areas. Mountains cover 24 per cent of the global soil surface. As these areas comprise 12 per cent of the global population which is a substantial share in the big picture of the earth, the literature on mountainous area relimitations is quite fundamental. (Kapos et al., 2000: 3; Huddleston et al. 2003; Wymann von Dach et al., 2016: 8; Veith and Shaw, 2011: 3). Mountains are complex and fragile ecosystems with distinct topographies, very diverse climatic conditions, and vertical processes. Therefore, relimitations of mountainous areas, which are described as fragile, were focused in seminal studies with national and international implications. These studies applied different relimitation methods for mountainous areas by examining natural environment characteristics, Geographic Information Systems and general information Kapos et al., (2000); Blyth, (2002); Meybeck et al., (2001); Sayre, Frye, Karagulle, Krauer, and Breyer at al., (2018); Jia, Tang, Liu, 2020; Kang, Lee and Cho (2020); Dal and Gönençgil, (2018); Price at al., (2018); ESPON (The European Observation Network for Territorial Development and Cohesion), (2012); Price and Butt, (2000); Peng, Hu, Qiu, Meersmans and Liu, (2019); Rodríguez-Rodríguez and Bomhard, (2012); Elibüyük and Yılmaz, (2010: 39); Debarbieux, Price and Balsiger, (2015); Dax, (2005).

However, it is necessary to make sense of the socio-economic characteristics in mountainous areas as a process of environmental effect on people and environmental changed caused by people to determine the values in these areas precisely. The mountain area relimitations on a national scale, in particular, were generally performed according to physical geography factors (Dal and Gönençgil, 2018; Elibüyük and Yılmaz, 2010: 39; Erol 1992). However, the economic and social characteristics that originate from the interaction of human and environment are omitted. This deficiency reveals the negativities, of human-based constraints on mountainous areas and sustainability activities, based on planning and management. Thus, the national economic and social evaluation analysis for mountainous areas comprise agriculture and livestock activities, tourism, residential characteristics, forestry and forest protection processes, cultural reserves generic to mountain areas, population characteristics, income sources diversification, infrastructure, health, education and local mountain development policies designed for these areas. These features are substantial for the mountain area development and the policies to be designed for development tools in these areas. Materializing of future sustainable development investments accurately and on time shall facilitate the determination of their impact levels. The mountainous areas analysis of Giresun, performed with consideration of the basic 
natural and socio-economic characteristics include subjective information based on locals regarding natural environmental conditions. This study propounds arguments that highlight the natural and socio-economic characteristics of the mountainous areas in Giresun and their regional impacts.

\subsection{Study Area Profiles}

Giresun province is located in northeastern Turkey, the Eastern Black Sea section of the Black Sea Region, between $40^{\circ}$ $07^{\prime}-41^{\circ} 08$ 'northern latitude, $39^{\circ} 50^{\prime}-37^{\circ} 12^{\prime}$ ' east longitude. It is surrounded by the Black Sea in the north, Ordu in the west, Sivas and Erzincan in the south, Trabzon and Gümüşhane in the east (Figure 1). The total surface area of Giresun is $6,972 \mathrm{~km}^{2} .{ }^{1}$ As of 2019, there are 24 municipalities, divided as 16 district municipalities and 8 town municipalities, 551 villages, 199 neighborhood settlements affiliated to the district centers and 1927 village affiliates in total. ${ }^{2}$

The most important mountainous area in Giresun is the Giresun Mountains, which are a part of the North Anatolian Mountains and constitute the higher parts of the province. Within the Giresun Mountains schema, Karagöl Mountains, Tutak
Mountain, Sis Mountain, Çaldağ and Sarıçiçek Mountains have particular importance.

The Giresun Mountains cover the fraction that includes the Karagöl mass, located in the Ordu-Giresun part of the Eastern Black Sea mountain range and extending between Aksu Valley in the east and Melet Valley in the west. In the western parts of the Aksu Basin on the eastern border forming the mountain mass, the elevation areas of $2000 \mathrm{~m}$ are less prevalent (de Planhol and Bilgin, 1961: 129). The highest part of the Karagöl mass in the entire spreading area is a dome-like anticline area on its southern edge. The highest points of this area form parts with an elevation above $3000 \mathrm{~m}$ such as Karagöl Mountain (3107 m) and Karadağ (Gavur Mountain $3331 \mathrm{~m}$ ) and these are located in the central and southeastern parts of Giresun. This area, which forms the highest parts identified to be anticlinal, consists of a granodiorites base. This base is covered with a series of more than $500 \mathrm{~m}$ at some points. The northern wing of this mass, which bears the most important geomorphological traces of the Giresun Mountains, is divided by four large valleys in S-N direction parallel to each other and deeply fragmented by Melet, Turnasuyu, Pazarsuyu, Batlamasuyu (de Planhol and Bilgin, 1961: 129-130; Gürgen, 1997: 150; Özdemir, 2017: 21-25).

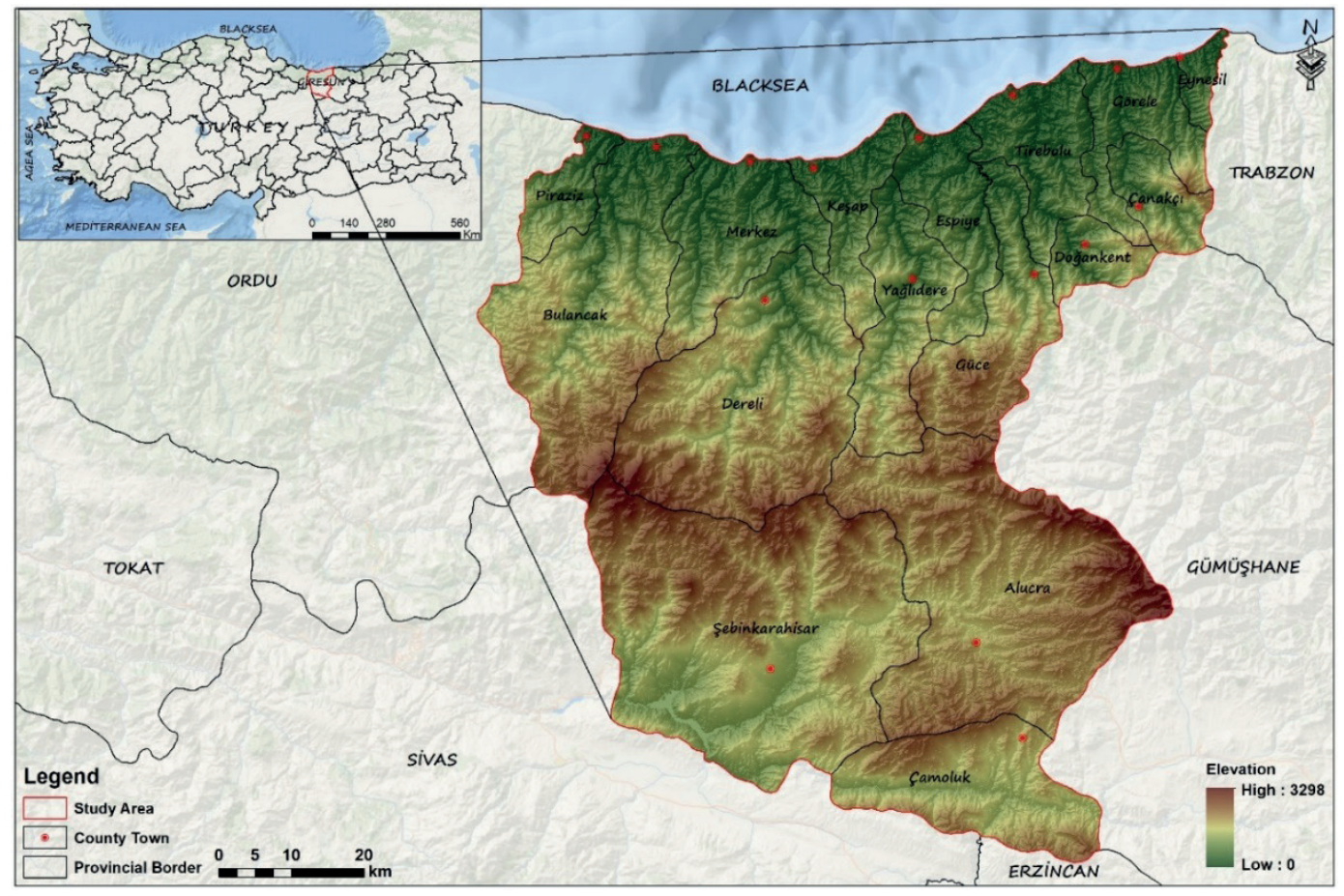

Figure 1. The geographical position of the study area.

1 https://www.harita.gov.tr/il-ve-ilce-yuzolcumleri

2 https://www.e-icisleri.gov.tr/Anasayfa/MulkiIdariBolumleri.aspx 
Besides the glacial forms in Giresun-Karagöl mountains, karstification is observable in Sarıçiçek Mountain due to geological formations. These karstification forms develop not in the whole of Sarıçiçek Mountain, but only on the mountainous areas suitable for karstification. The most important forms of karst morphology in these areas are defined as doline, sinkhole and directed karst (Uzun, Zeybek and Demirağ, 2012: 20-23). The Örencik and Aktepe settlements, located between Düzdağ and Sarıçicek Mountains, are fragmented through the basaltic rocks due to suitable conditions of the climate. This fragmentation allows the formation of the toroid topography in Örencik and Aktepe villages (Uzun, Zeybek and Hatipoğlu, 2012: 9-13). The highest point of Sis Mountain, at $2182 \mathrm{~m}$, is composed of neogene erosional surfaces and deeply split valleys along the river valleys (Keçer, 1993).

The abundance of the areas covered by the mountains in Giresun province caused differences in slope values as a result of the effect of the elevation factor on the study area, erosion and accumulation activities of the rivers (Table 3 ). This fractionation of mountainous areas is more prevalent in the Eastern Black Sea region, where Giresun province is located, which is featured by its high density of mountainous areas in comparison to other regions of Turkey (Elibüyük and Yılmaz, 2010: 39).

When the slope averages are considered in Giresun which has a $6,972 \mathrm{~km}^{2}$ area, it is observed that areas with the highest slopes range between $35^{\circ}$ and $63.2^{\circ}$ and totaling $54,21 \%$ of the surface area $\left(3779,5 \mathrm{~km}^{2}\right)$. These areas are generally concentrated on the valley slopes formed due to deep erosion of the Giresun Mountains, which are generally defined as backshore, and the streams that are the extension of individual mountain branches, and in the Northeast part of the study area where Topuklu Mountain, Sis Mountain and Gidek Mountain are located. These slopes have a narrowing effect on several economic activities such as transportation, infrastructure, housing, agriculture, which derive their resources from human activities. The areas within the lowest slope class ranges between $0^{\circ}$ and $3^{\circ}$ that cover $1.94 \%\left(135,3 \mathrm{~km}^{2}\right)$ of the area also constituting the coastline and beach zones. These areas have more favorable conditions in terms of economic activity processes compared to other slope classification fields. The slope values southern parts of the Giresun Mountains, which are defined as plateau areas throughout the province, the central parts of the Karagöl Mountains, in the areas where Düzdağ and Sarıçicek Mountains are located, range between $6.01^{\circ}$ and $12^{\circ}$ $-12,01^{\circ}$ and $17^{\circ}$ covering $21,1 \%\left(1471,2 \mathrm{~km}^{2}\right)$ of the total area (Table 1; Figure 2)
Table 1. Slope Values for Giresun Province.

\begin{tabular}{ccc}
\hline Area $\left(\mathbf{K m}^{2}\right)$ & Slope Value $\left(^{\circ}\right)$ & $\%$ \\
\hline 135,3 & $0-3$ & 1,94 \\
1160,4 & $3,01-6$ & 16,64 \\
309,2 & $6,01-12$ & 4,43 \\
1162 & $12,01-17$ & 16,67 \\
425,9 & $17,01-35$ & 6,11 \\
3779,5 & $35,01-63,2$ & 54,21 \\
6,972 & & 100 \\
\hline
\end{tabular}

\section{METHODOLOGY}

Mountainous area relimitations are implemented on the basis of the integrity of these areas through the physical geography characteristics. Giresun's mountainous areas relimitations were materialized thanks to Erol's (1992) 1/1,000,000 scale Turkey Geomorphology Map prepared for the General Directorate of Mineral Research and Explorations, Keçer's (1993) Giresun Geomorphology Map prepared with the $1 / 250,000$ scale, and Dal and Gönençgil's (2018) work asserting the national scale relimitations in mountainous areas. Digitization processes were performed in Geographical Information Systems using a highresolution Digital Elevation Model (DEM) (25 m meshed grid), $1 / 25.000$ and $1 / 100.000$ scaled topography maps. Through the obtained Digital Elevation Model data, natural slope values in mountains areas were determined after the slope analyses. Field measurements were conducted in Geographical Information Systems programs to utilize slope values in mountainous areas. The socio-economic analysis was utilized after the relimitation implementation with regards to the physical integrity and natural environmental conditions in Giresun. It comprises the human and land information elements, policies and practices in mountainous area development, environmental, economic, social and cultural sustainability issues (Figure 3).

The mountain areas of Giresun are divided into impact zones following the physical geography analysis as well as residential features and impact area research in these areas. This relimitation has been applied to the study within a consideration of the human geography characteristics of the mountain areas, population, agriculture and livestock, forestry, income source diversification, cultural reserve, tourism, housing, infrastructure, education, health, zone management and mountain policies. Criteria suggestions to be applied in mountain areas that will be analyzed through human geography characteristics include various rural characteristics with local nuances. These criteria have been chosen based on the differences in life characteristics of rural and urban areas and their potential effect on the mountain area development in socio-economic terms. These criteria amplify 


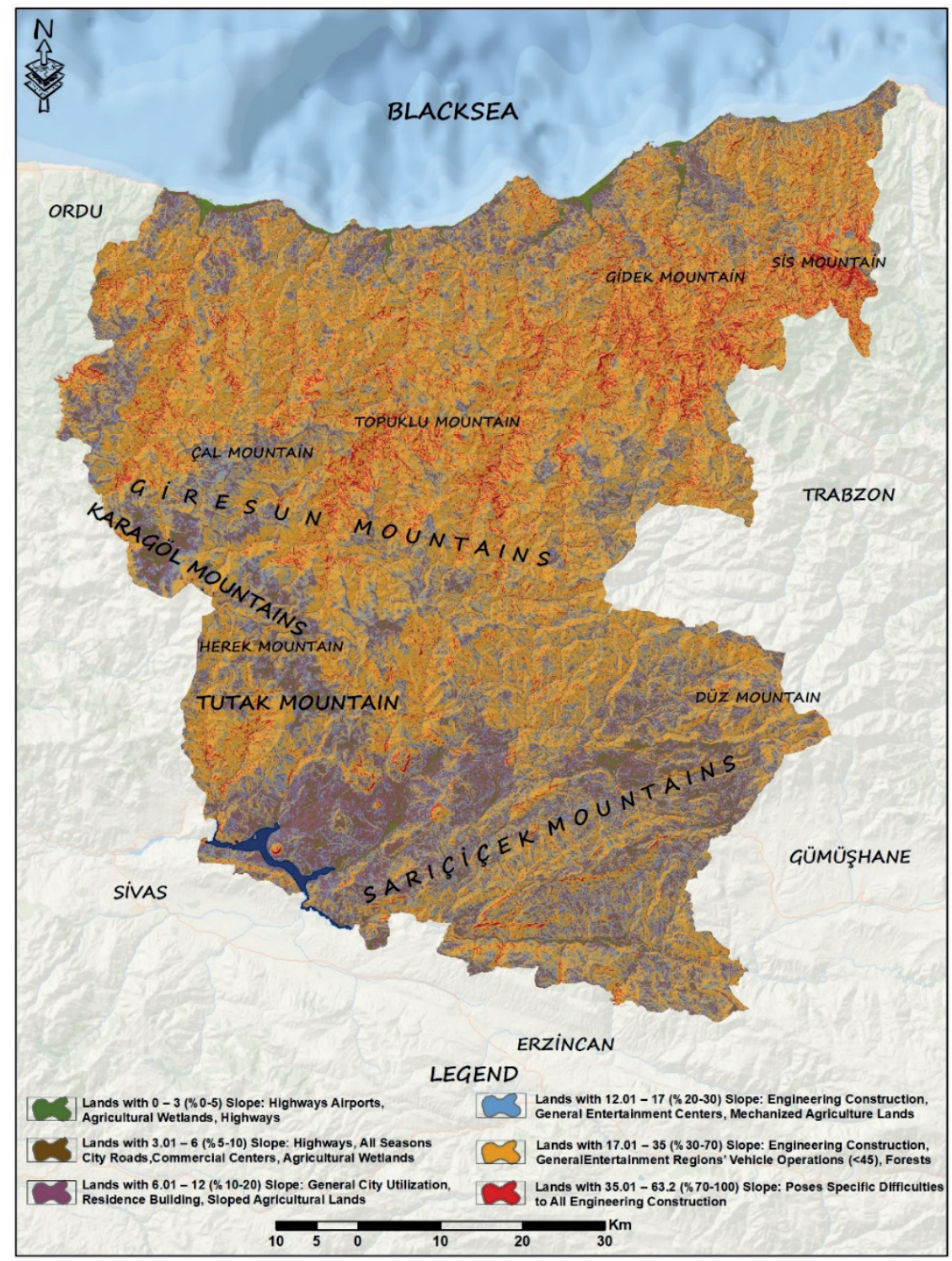

Figure 2. Slope Map of Giresun Province.

and may change according to diverse mountain science policies applied in mountainous areas. Mountain area values are defined by the social reserves of the locals and the environmental features (Figure 4).

\section{RESULT AND DISCUSSION}

\subsection{Limitation of Mountainous Areas in Giresun Province}

The mountainous areas that vary with geographical conditions are generally specified with natural environment characteristics, considering the elevation and slope factors. Topographic data from GTOP030 global digital elevation model were utilized by U5GS EROS Data Center 1996 to generate slope and local elevation range in a 30 arc-second network of the world. Mountain kinds according to this elevation model range are based on continental sub-groups in analysis and equal conical projection to reduce projection distortion in the original data set. The mountain areas of the world are, claimed by some authors, limited into following three classes. only by elevation These are qualified as 2500-3499m; 3500-4499m and $>4500 \mathrm{~m}$. However, in narrower areas, if a land between 1500 and $2499 \mathrm{~m}$ has more than a $2^{\circ}$ slope, it is classified as a mountain. This threshold has proven to be accurate in eliminating medium-height plateaus. Lands between 1000 to $1499 \mathrm{~m}$ elevation that has more than $5^{\circ}$ slope threshold, with a local range of $300 \mathrm{~m}$ or more, are also classified as mountains. The lands with an elevation between 300 and $999 \mathrm{~m}$, and a local altitude range of $300 \mathrm{~m}$ or more, is 


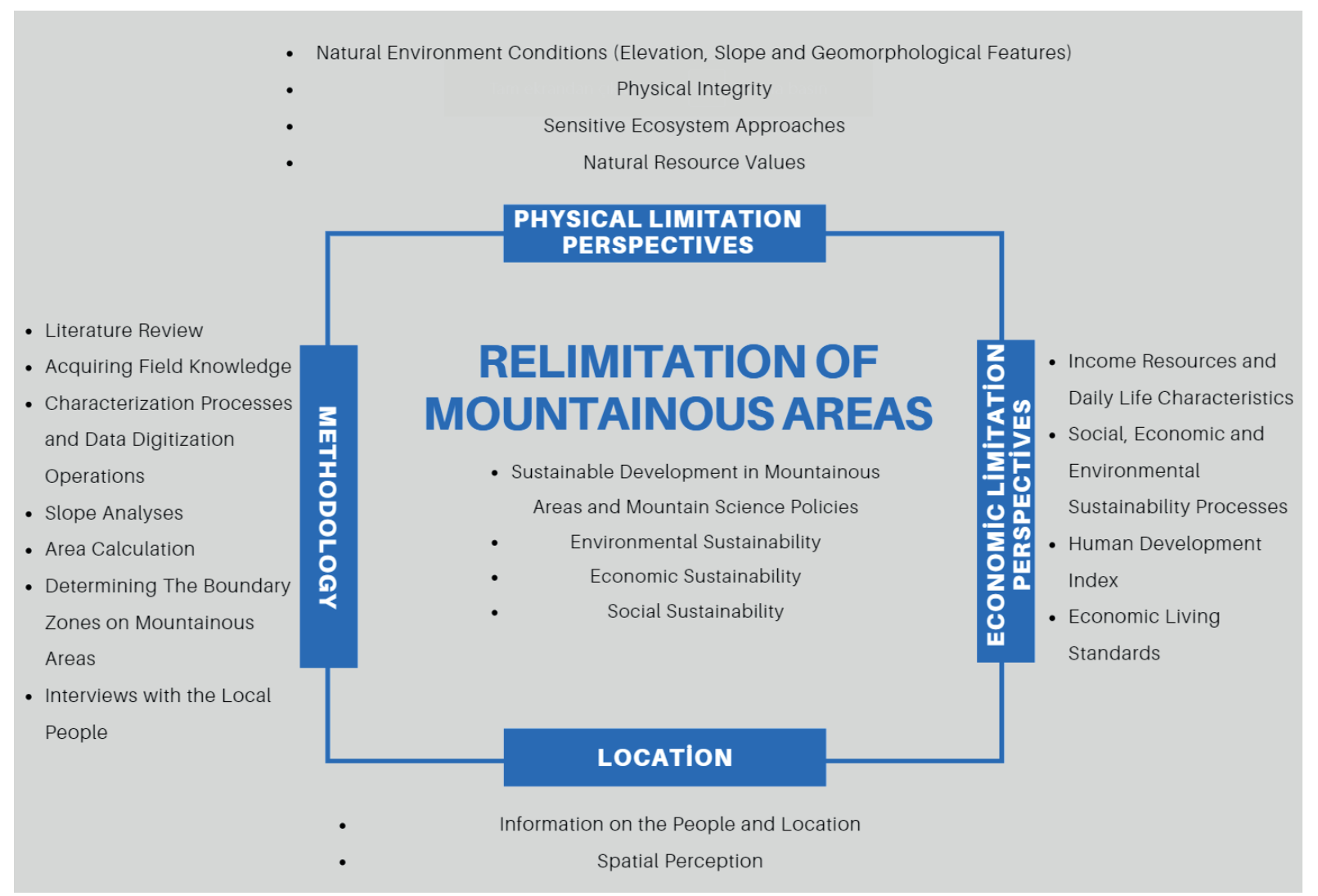

Figure 3: Sustainable Development Systematics in Mountain Areas and Case Analysis for Giresun (modified Messerli, 2012: 60).

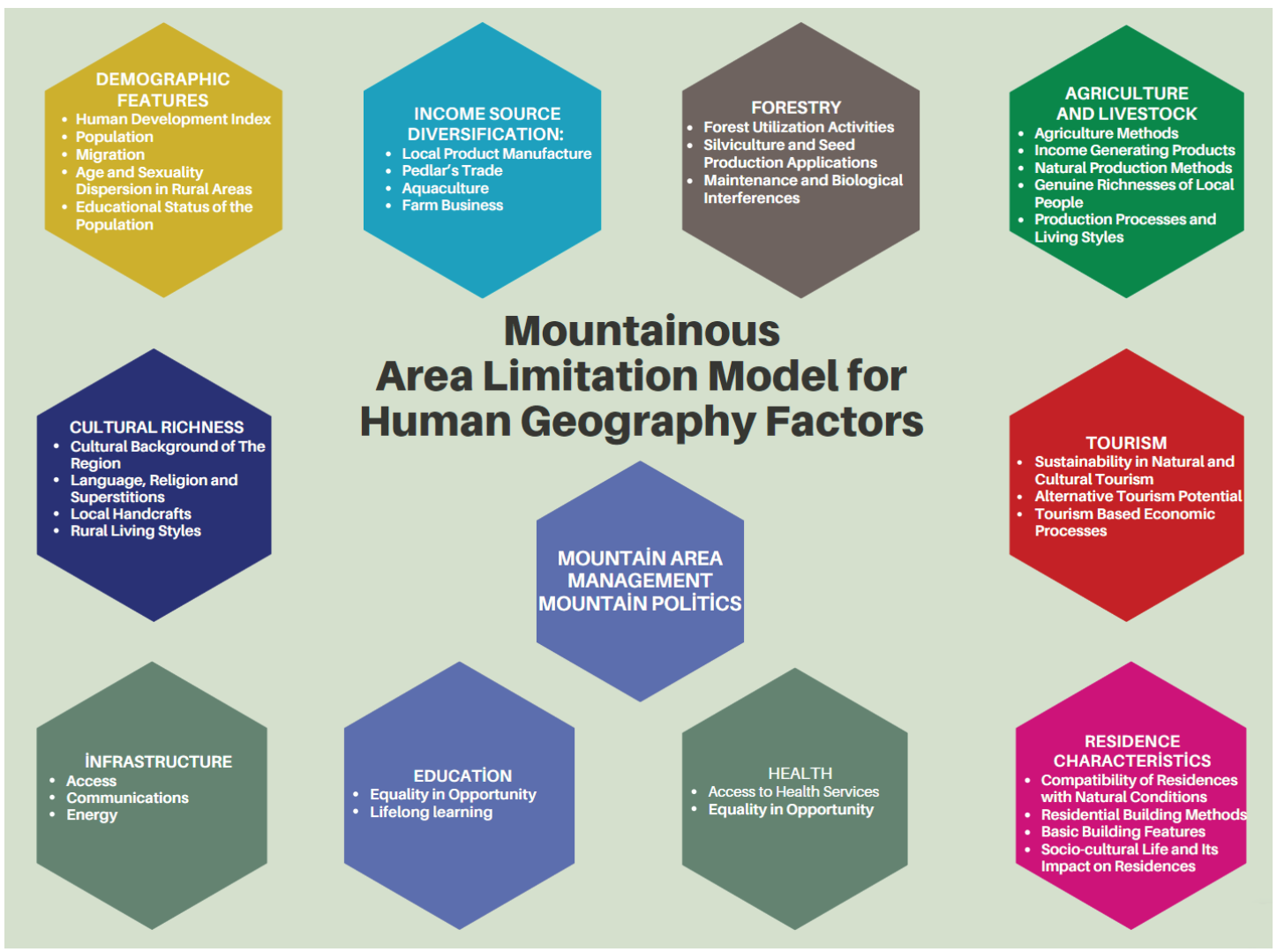

Figure 4. The Applicable Criterion Model for Mountain Areas Relimitation Analyses with Human Geography Characteristics. 
classified as a mountainous area (Kapos et al., 2000: 6). When the areas covered by mountains on earth are considered according to the applied height ranges, it is stated that the areas in the 300$999 \mathrm{~m}$ range have the highest geomorphological proportion. However, sites that do not meet any of the 6 criteria are designated as isolated inland basins and areas less than $25 \mathrm{~km}^{2}$ (Blyth, 2002: 74; Table 1).

According to the digital elevation model created in another study, the surface slope ratios were used by dividing the entire land surface into 15 typological classes. In this classification, the area covered by mountains is measured as 33.5 million $\mathrm{km}^{2}$ accordingly with the slope levels. However, the total measurements of all of the classified areas are 133 million $\mathrm{km}^{2}$ (Table 2).

The above mentioned differences are reflected in characterization studies with different GIS methods in mountainous area limitation (Sayre, Frye, Karagulle, Krauer, \& Breyer, 2018: 240-249; Dal \& Gönençgil, 2018). There is no exact information on how and with what method the mountainous area limitation should be implemented. It is not possible to provide a certain height range in mountainous area limitations that may vary locally and regionally. However, it should be indicated that the economic and socio-cultural processes in the mountainous areas and regions close to the mountainous areas, impact zones of the mountainous areas, are also effective in these studies.

The boundaries of mountainous areas in Giresun province were determined based on the results of Geographical Information Systems and field observations. According to the findings obtained, the mountainous areas in Giresun were determined as $4,518 \mathrm{~km}^{2}$, and the impact zones of the mountainous areas were determined as $2,454 \mathrm{~km}^{2}$. In this regard, within the province of Giresun; the districts of Çanakçı, Güce, Doğankent, Alucra, Çamoluk, Dereli and Yağlidere are located in the mountainous areas, while much of the districts of Bulancak, Espiye, Eynesil, Central District, Görele, Keşap, Piraziz, Şebinkarahisar and Tirebolu are located in the impact zones of the mountainous areas. In Şebinkarahisar, Çamoluk, Alucra district centers and their immediate surroundings, there are particular sites that have

Table 1. Mountainous Area Limitations According to the GTOP030 Global Digital Elevation Model.

\begin{tabular}{|c|c|c|}
\hline Elevation Limit & Slope Criteria & Surface Proportion of Earth \% \\
\hline$>4.500$ & & 1,2 \\
\hline $3.500-4.499$ & & 1,8 \\
\hline 2.500-3.499 & & 4,7 \\
\hline $1.500-2.499$ & $>2^{\circ}$ Slope & 3,6 \\
\hline $1.000-1.499$ & $>5^{\circ}$ Slope or Local Elevation Value $>1000 \mathrm{~m}$ & 4,2 \\
\hline $300-999$ & Local Elevation Value $>300 \mathrm{~m}$ & 8,8 \\
\hline Isolated inland basins and plateaus areas less than $25 \mathrm{~km}^{2}$ & Fields surrounded by mountains but do not meet the $1-6$ criteria & \\
\hline
\end{tabular}

Source: updated from Kapos et al., 2000: 3; Price, 2013: 4; Blyth, 2002: 74.

Table 2: The Distribution of Slopped Areas around Mountainous Areas in the World.

\begin{tabular}{|c|c|c|c|}
\hline Slope (\%o) & Total Area km² & $\%$ & Sample Areas: (Europe, Asia, Africa, North America, South America, Australasia) \\
\hline$<5$ Near Horizon & 33,2 & 25 & $\begin{array}{l}\text { Western European Plains; Caspian Plains, West Siberian Plain, Greater China Plain, Karakorum, Takla } \\
\text { Makan, Mesopotamia, Chad Basin, Sudd, Congo Basin, Kalahari; Gulf of Mexico Coastal Plain, North } \\
\text { American Plains; Central Amazon Basin, Gibson Desert, Nullarbor Plain, Simpson Desert, Murray Basin }\end{array}$ \\
\hline 5-10 (Very Flat) & 25.9 & 19.5 & Britain, Southern Sweden; Deccan, Gobi Desert, Nedj Plateau, Zereh Depression, Thar; \\
\hline 10--20 (Flat) & 23.7 & 17.8 & $\begin{array}{l}\text { Fezzan, Katanga, East African Lakes Plateau, South Africa Veld; Labrador, Great Plains; Mato Grosso, } \\
\text { Tumuc Humac; MacDonnell Series, Barkly Plateau, Kimberley Plateau }\end{array}$ \\
\hline $20-40$ & 22.4 & 16.8 & Iceland, Massif Central, Spain, Central Sweden, Carpathian Mountains, Ural; Siberian Plateau, \\
\hline $40-80$ & 19.5 & 14.7 & $\begin{array}{l}\text { Outer Mongolia, Tibet, Iranian Plateau, Armenian Plateau, Anatolian Plateau, Hadramaut; Tellian Atlas, } \\
\text { Hoggar, Tibesti, Adamawa, Namib Desert, Zimbabwe, Appalachian Mountains, Great Basin, Columbia } \\
\text { Plateau, Colorado Plateau, Mexican Plateau, Sierra Madre Orientale; Australian Alps, New Zealand Alps }\end{array}$ \\
\hline $80-160$ & 7.67 & 5.8 & $\begin{array}{l}\text { Pyrenees, European Alps, Dinarites, Coastal Norway, Pontorana Mountains, Pamir, Hindu Kush, Altai } \\
\text { Mountains, Zagros Mountains, Elbrus, Greater Caucasus, Lesser Caucasus, Taurus Mountains, High } \\
\text { Atlas Mackenzie Mountains, Coastal Range (British Columbia - Oregon), Coastal Cordillera Andes, The } \\
\text { Eastern Cordillera of the Andes; Maoke Mountains }\end{array}$ \\
\hline$>160$ & 0.56 & 0.4 & $\begin{array}{l}\text { Parts of the European Alps; most of the Himalayas, Pamir and part of Karakorum, part of Alaska; parts } \\
\text { of the Andes }\end{array}$ \\
\hline Total & 133.000 & 100 & \\
\hline
\end{tabular}

Source: updated from Meybeck et al., 2001: 35 
the characteristics of an isolated basin, which are surrounded by mountains, but do not qualify as mountainous areas. These sites are included in the impact zones of mountainous areas (Figure 5).

\subsubsection{Population Characteristics within Mountainous Area} Limitation

Implementing sustainable development practices in mountain areas within the systematic planned requires a comprehensive understanding of the natural environment and population characteristics. Population and settlement areas, mountainous areas, which are included in the boundaries of mountainous areas in terms of natural environment characteristics but not in this areas after the relimitation are defined as impact zones. According to the Turkish Statistical Institute data of 2019, the province has a total population of 448.400 of which 148.303 live in rural areas and 299.792 in urban areas (Turkish Statistical Institute, 2019). In this context, the arithmetic population density in Giresun is 64 people per $\mathrm{km}^{2}$. The observations indicated that the total population of 7 district centers (Çanakçı, Güce, Doğankent, Alucra, Çamoluk, Dereli, Yağlıdere) included in the mountainous areas of Giresun was determined as 33.935. In addition to the

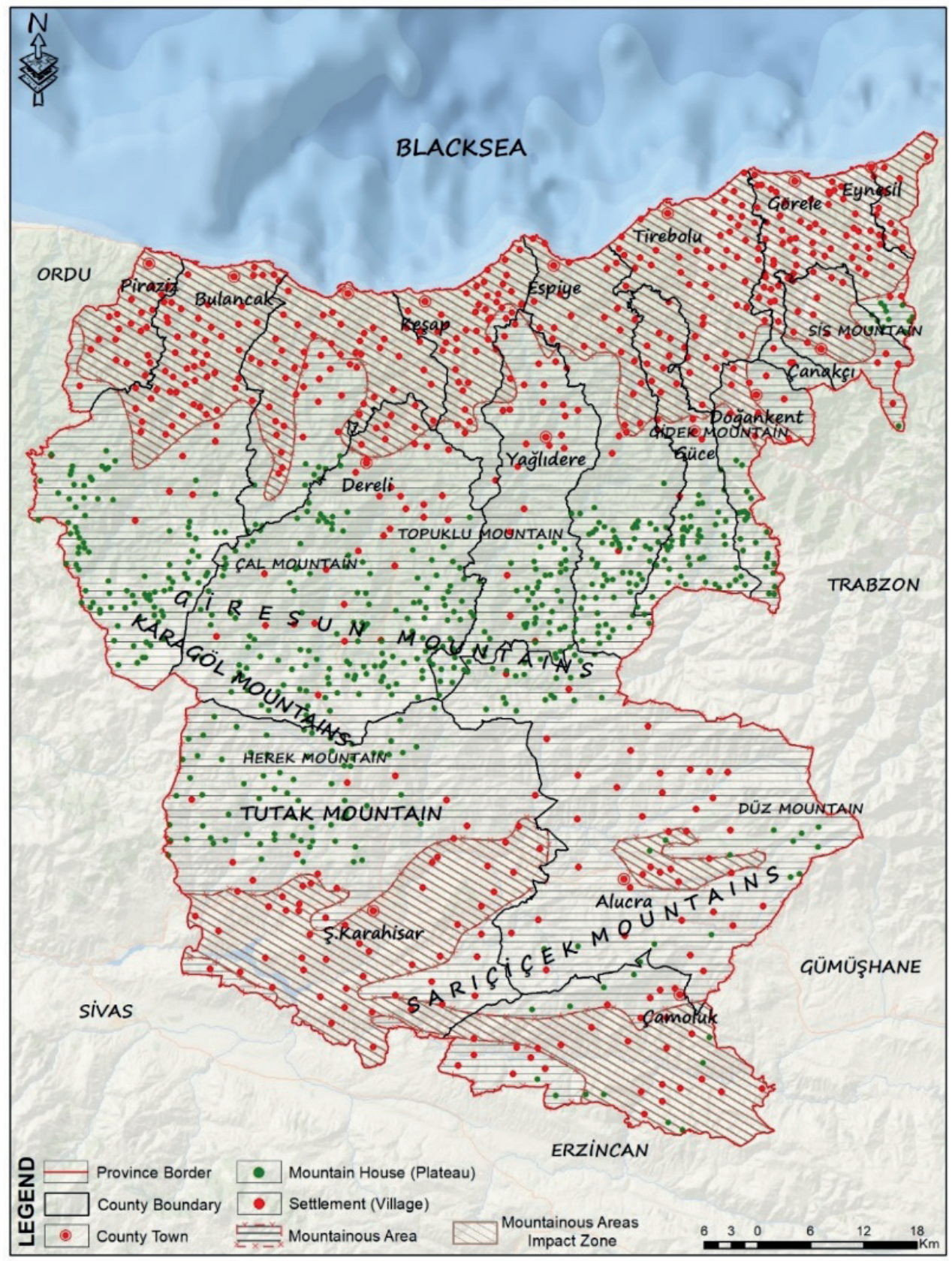

Figure 5. Giresun's Mountainous Areas and Relimitation Map in the Impact Zones. 
district centers, there are 159 village settlements included in the mountainous area boundaries and the total population of these village settlements has been determined as 36,747 . Thus, a total of 70,682 people live in mountainous areas. Despite the low amount of population in mountainous areas that are permanently resident, the population numbers in these areas may increase seasonally or periodically. Furthermore, the 370 of the 378 plateau settlements and 160 nomad camps in Giresun, which are used periodically, are within the boundaries of the mountainous area (Figure 5).

The determination of economic utilities in mountain areas is reflected in the country's development index. Detailed researches included in the calculation of the development index, involves criteria such as housing, working life, income and wealth, health, education, environment, security, civic participation, access to infrastructure services, social life and life satisfaction which affect the calculation of general development index. Some of the criteria contributing the general development index in Giresun has the following values as Housing satisfaction 0,8598, Education 0,6683, Security 0,6683, Work Life 0,5611, Income and Wealth 0,4017, Health 0,6830, Environment 0,6032 , Security 0,7376, Civic Participation 0,3954, Infrastructure 0,4013, Social Life 0,4633 and Life Satisfaction 0,6581 (Turkish Statistical Institute, 2015). Migration, which is one of the most important population-related problems in the mountainous areas of Giresun, the decrease in the young population and the desolation of mountainous areas cause various difficulties in the application of sustainable development qualifications.

\subsubsection{Sustainable Agriculture and Livestock Within Mountain Area Limitation.}

The most important income-generating agricultural product located in the mountainous areas and impact zone of Giresun is hazelnut cultivation. In areas where natural environmental conditions are suitable for hazelnut cultivation, hazelnuts are picked collectively with the integration and cooperation of local people. The hazelnut fruit, which is collected with great effort in July and August every year, is one of the main income-generating activities of population and a source of unity in mountainous areas in sociological terms (Figure 6).

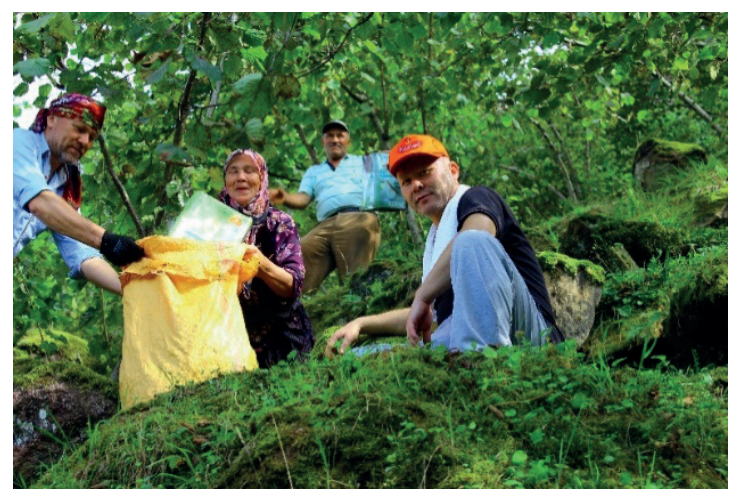

Figure 6. Hazelnut Picking in Mountain areas of Giresun.

Several incentives are implemented for the sustainability of agriculture in mountain areas and to increase the number of farmers engaged in agriculture. Under these incentives, 248 projects were implemented as part of the young farmer project realized in the mountainous areas of Giresun. 38 young farmer projects in Bulancak district on the Karagöl mountains, 30 in Dereli district, and 46 were realized in Şebinkarahisar district, which borders the Sariçiçek, Herek and Tutak mountains. The good agriculture project is also implemented to support agricultural sustainability in mountainous areas, as 762 farmers applied with 308 tons of agricultural production outcome (Giresun Provincial Directorate of Agriculture and Forestry, 2018; Figure 7).

Livestock activities related to agriculture are commonly utilized, especially in the highlands, which are specified with Alpine vegetation. Animal husbandry is one of the main sources of income for people living in the high parts of mountainous areas that are used seasonally or periodically. Especially the

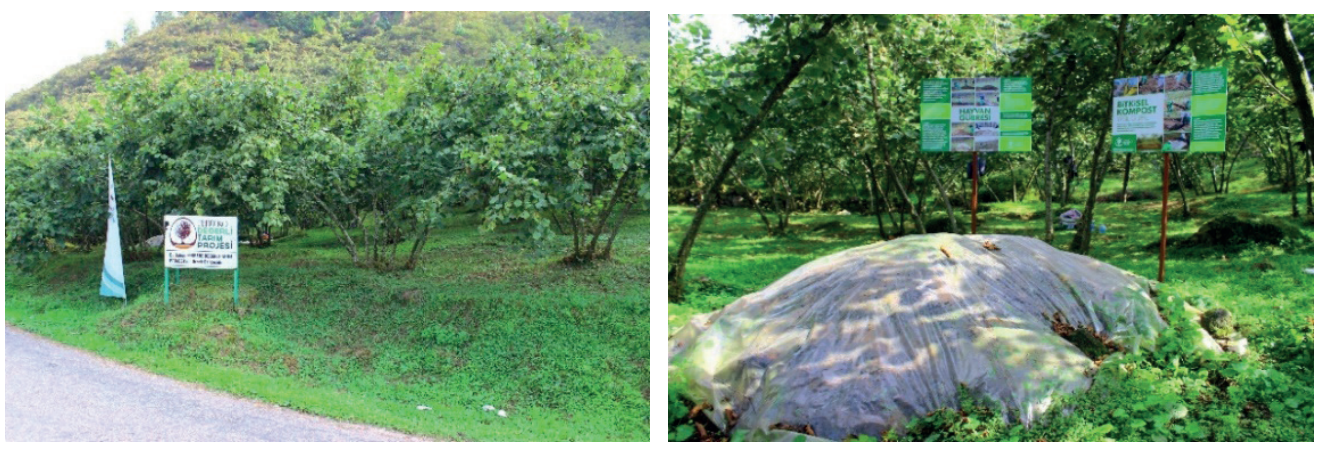

Figure 7. Examples of Good Agriculture Lands in the Karagöl Mountains of Giresun. 
animals raised in these areas and the animal products obtained are offered for sale on particular days in the markets established in certain settlements (Figure 8).

IPARD (Instrument for Pre-Accession Assistance-IPA), which is carried out as a European Union equivalent project is organized by the Agriculture and Rural Development Support Institution. This institution is established to conduct activities for the implementation of rural development programs, including the resources provided from the European Union and international organizations, under the framework of the principles and targets projected in the national programs and strategies. As a result of the IPARD I, support applications made between 2013-2019, the milk production enterprises, which will be established with a capacity of 70 animals, was offered for the first time throughout the province. To ensure sustainability in the livestock sector, the target is to produce a minimum of $5 \%$ of the cattle production (40 plants each with 100 units) in EU standards. In addition, there are available projects with the breeding cattle raising association model in Çamoluk, Alucra and Şebinkarahisar districts located in the Herek, Tutak and Sarıçicek mountains areas of Giresun province, which are suitable for cattle and ovine breeding, to enable the cattle breeding enterprises to function at the minimum sizes (dairy enterprises 10 units, meat enterprises
30 heads). Contracts worth 25 million TL have been signed in Giresun province under IPARD I and II incentives (Agriculture and Rural Development Support Institution, 2019).

Most of the cattle breeding in the mountainous areas of Giresun stands out as the basic subsistence livestock activities. Especially the existence of pastures and meadows in these areas contributes significantly to livestock raising. Cattle raising and sheep \& goat farming are also used for commercial purposes in areas where natural grazing methods are used (mostly Alpine belt) in addition to subsistence activities (Figure 9). These production activities in the sections defined as the nomad camp and plateau zone also include the processes of organic food production for commercial purposes. The majority of butter, cheese, honey and red meat production, which stands out as animal products, especially during the weekends and summer months, is used for commercial purposes in highland tourism centers, close to protected areas.

\subsubsection{Forestry Activities Within Mountain Range Limitation}

Besides the agriculture and livestock among the economic activities in Giresun, forestry activities have become a subsistence source of the people living in the village areas. Hence, the
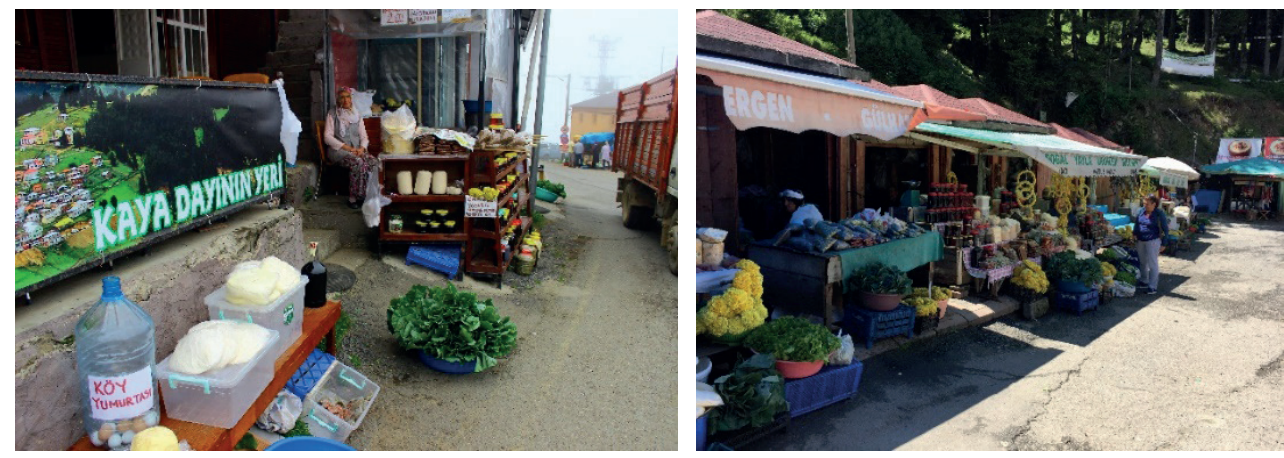

Figure 8. Livestock Products Sale Areas in Giresun Karagöl Mountains.
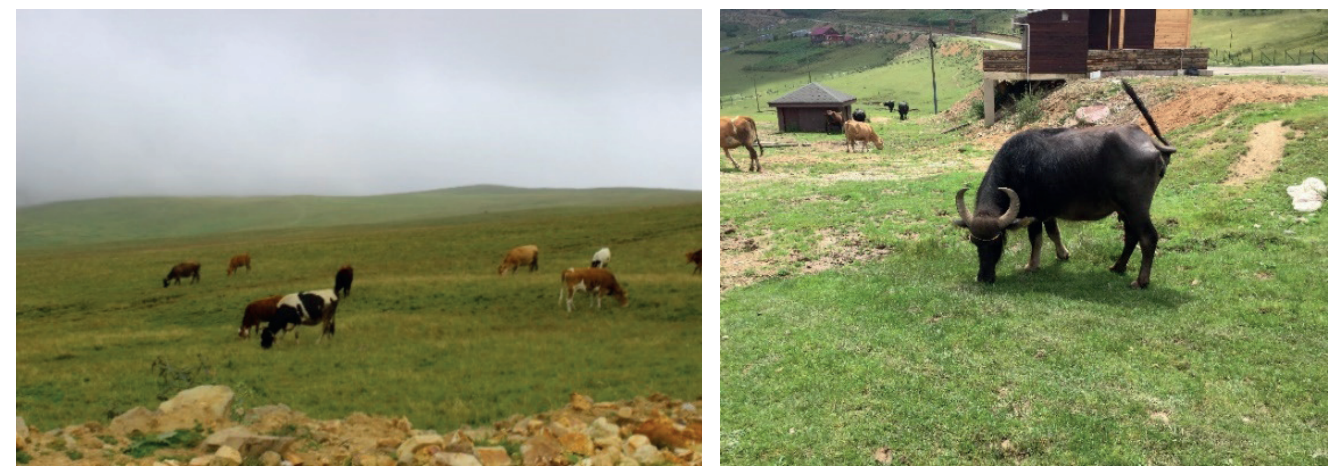

Figure 9. Sheep and Cattle Breeding in Giresun Mountains. 
proximity of village settlements in Giresun to forest areas is important for economic subsistence and commercial activities. The people, who benefit from forests in the form of production and provision, can earn financial income from these areas and contribute to production. 285 of the 551 villages in Giresun province are in or adjacent to forests. In 2018, a total of 6,070 hectares of forest area, including 1.109 hectares of regeneration and 4.961 hectares of maintenance, were included in the sustainability processes under the forest protection processes in the mountainous areas of Giresun. Silviculture practices are carried out in several parts of the mountainous areas of Giresun. These practices are carried out in the central parts of Giresun mountains and within the Dereli forestry, which borders the Karagöl mountains. The silviculture plans to be realized between 2013-2032 in Giresun belong to the Kümbet, İkisu and Dereli branch management. Activities to be implemented within the scope of sustainability and protection of forest areas and forest products manufacture from these areas are projected to be realized on 433.2 hectare of Kümbet enterprise, 291,5 hectares of İkisu branch management and 179,8 hectares at Dereli branch management. Along with silviculture processes, seed production farms have been established to ensure forest sustainability in mountainous areas. A total of 17.4 tons of seeds were produced between 2010 and 2019, depending on the Giresun Provincial Directorate of Agriculture and Forestry. (Giresun Provincial Directorate of Agriculture and Forestry, 2019). An insect called Rhizophagus grandis is produced through a private laboratory within the Directorate of Kulakkaya Forest Management to combat pests that are common in forest areas to ensure forest sustainability for biological control purposes. This insect species is an important predatory species for the protection of the Eastern Spruce and forest sustainability against the bark eating pest known as Dendroctonus micans (Figure 10).

\subsubsection{Income Source Diversification within Mountainous Area Limitation}

Local product manufacture, conducted within the scope of income source diversification in the mountainous areas of Giresun includes not only the food and beverage culture but also the processing of raw materials obtained from agriculture and livestock into products that reflect the regional culture. In terms of product diversity, the transformation of daily activities in mountain areas from subsistence to a commercial nature is
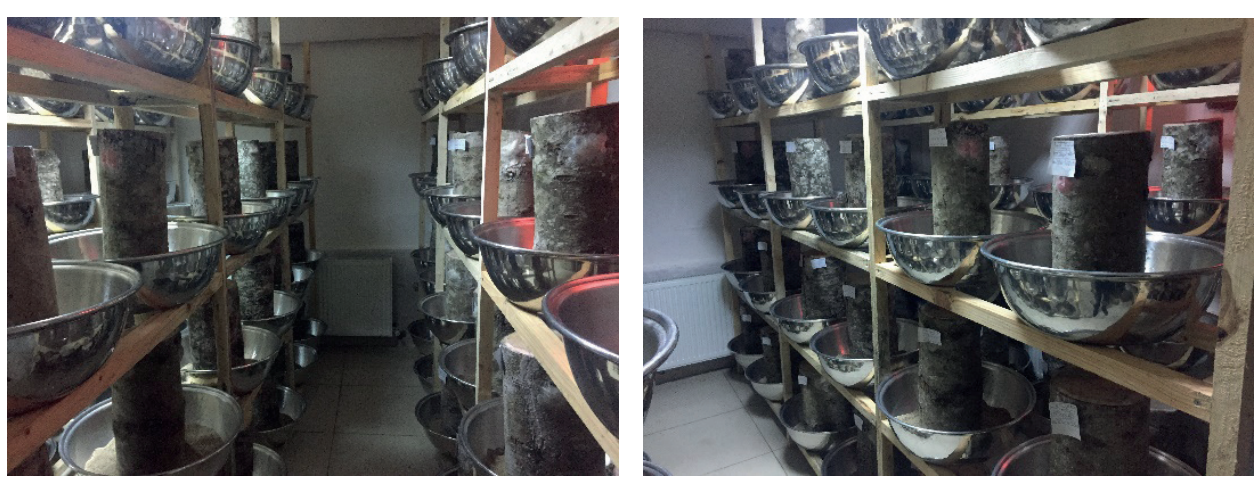

Figure 10. The Facility Established for Biological Control in Mountainous Areas of Giresun.
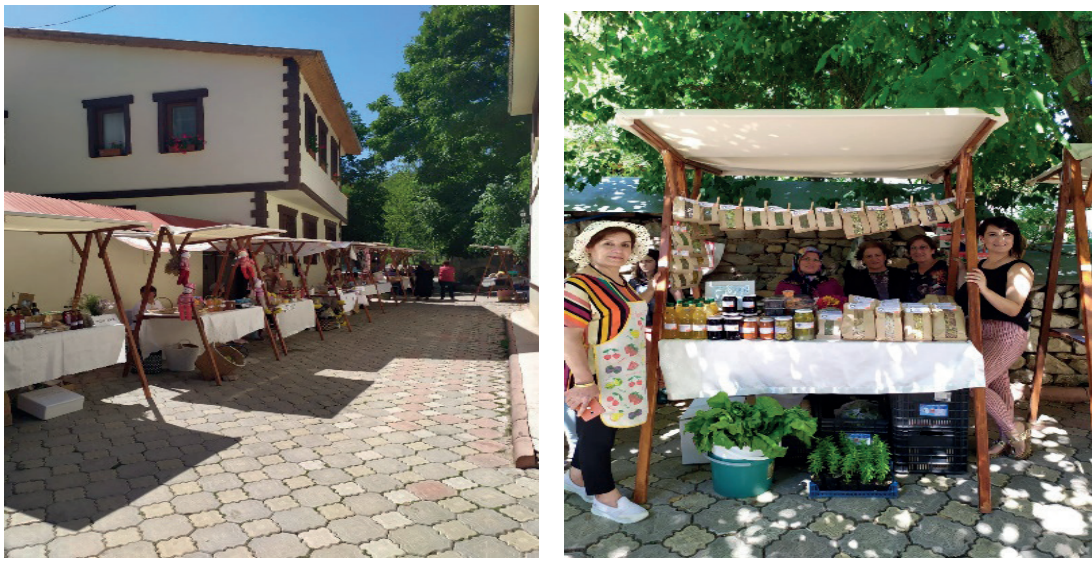

Figure 11. Ecological Market Practices in Mountain Areas of Giresun. 
actually the result of various female labor incentives and encouragement. An example of these practices is the ecologic market in the Tamzara neighborhood, which is located close to the Tutak and Herek mountains. Local people have the opportunity to sell the local organic products they produce in these markets (Figure 11).

Aquaculture, which is one of the activities for alternative income sources in the rural development focus, is carried out in Giresun for subsistence and commercial purposes. There are a total of 58 fish farms (including non-functioning ones) throughout the province of Giresun. Majority of these fish farms are located in the central parts of Giresun Mountains and Karagöl Mountains (Figure 12).

\subsubsection{Sustainable Residence Characteristics within Mountain Area Limitation}

Residences in mountainous areas are shaped by environmental conditions. The residences that are in constant interaction with different climatic and vegetation conditions vary in the mountainous area limitation of Giresun. In the study area, where stone and wood residences are generally existent, the past experiences in terms of sustainability are transferred to the modern-day projects and the conservation of residences with the retainment of settlements are ensured (Zaman 2017; Koday et al. 2017; Kaymaz et al. 2017; Figure 13).

The basis of supporting sustainable human settlements includes social and cultural sustainability. These ideas caused the local architecture to gain a characteristic feature in the Eastern Black Sea Region. Techniques in the construction of wooden and stone residences from the past to the present reflect the sense of self-identity and commitment to the environment surrounding in which the people live in rural and urban residences. Today, building styles, which maintain slightly distancing from traditionalism, have changed with the impact of human factors. This effect has led to changes in residential types both in rural and urban areas by the development of different techniques.

\subsubsection{Sustainable Tourism within Mountain Area Limitation}

Tourism is among the main economic activities in the mountainous areas of Giresun province. The abundance of natural resources in the study area has enabled the development of opportunities such as mountain tourism and green tourism. Protected and sensitive areas developed thanks to tourism, diversification of value qualities with tourism potential shine out in the development of mountainous areas of Giresun as in other similar areas (Li et al. 2016). Some of those areas are Eğribel-
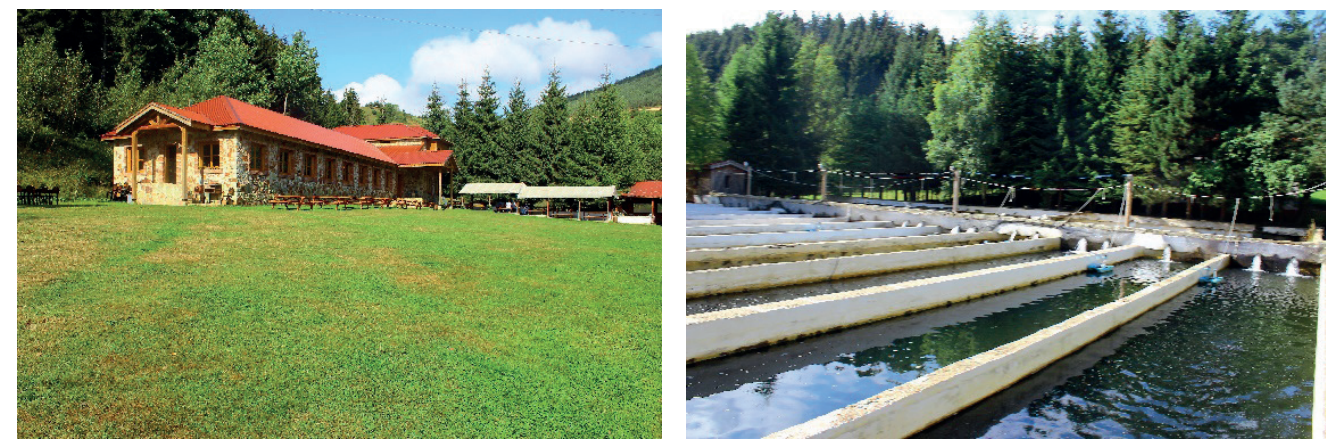

Figure 12. An Aquaculture Facility in Mountainous Areas of Giresun.
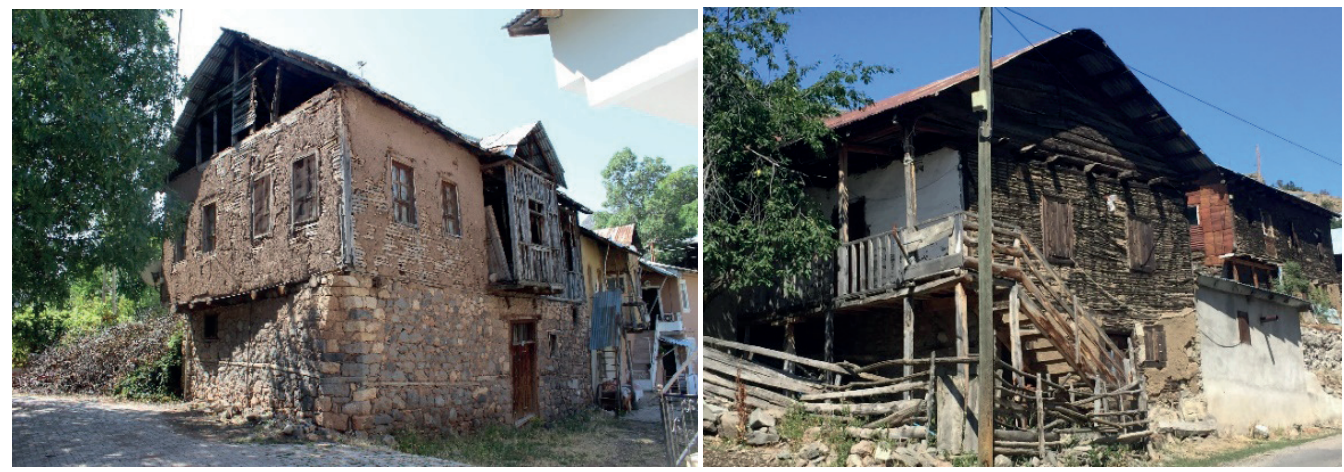

Figure 13. Traditional Residence Types in Mountainous Areas of Giresun. 
Kurtbeli prospective national park area, Ağaçbaşı nature park, Koçkayası nature park, Kuzalan waterfall nature park (Figure 14), Yedideğirmenler cave and nature park, Köroğlu nature park, Şebinkarahisar waterfall prospective nature park area, Gölyanı Plateau sensitive area for conservation and Aymaç prospective nature park (Bekdemir and Sezer, 2016; Koday, Kaymaz and Kaya, 2018). Moreover, for the purpose of protecting and maintaining the mountainous areas in the province, Karagöl Mountain prospective natural monument field, Şahinkayas1 prospective natural monument field, monumental tree prospective conservation areas, and hunting grounds for the control and protection of wildlife and fauna features such as Ambardağı, Bicik, Bulancak, Paşakonağı official hunting grounds and prospective village wildlife development areas such as Şebinkarahisar Arslanah-Dereköy-Uğurca have been identified as protected areas Ecotourism, mountain, plateau and festival tourism are among the most popular types of activities that develop in the mountainous areas of Giresun province.

7 areas have been categorized as mountain areas ecosystems by the Directorate of Nature Conservation and National Parks in Giresun. These places include Karagöl Mountains (Figure 14), Gavur Mountains, Tutak Mountain, Sisdağı, Çaldağ, Eğribel Pass and Kurtbeli Pass. The aforementioned areas are nationally acknowledged (Provincial Directorate of Nature Conservation and National Parks). These mountain area ecosystems include several protected areas including Giresun mountains. They are seen as areas where tourism processes are concentrated in mountain areas.

\subsubsection{Cultural Accumulation within Mountain Area Limitation}

The historical value of the mountainous areas of Giresun has enabled the development of cultural accumulations that have various potential in different sectors. The traditions, lifestyles, language and ethnic differences of the local people, local handicrafts and cultural accumulation reflections of rural residences that have resource value depending on this richness affect the limitations of the mountainous area. There are 20 churches, 32 mosques, 6 castles and 38 historical arch bridges included in the cultural inventory in the mountainous areas of Giresun where rural life culture is quite developed. Furthermore, the "Bird Language", which reflects the historical traces of the language culture by the people in Kuş village of Çanakçı district, was included in the UNESCO Intangible Cultural Heritage List Requiring Emergency Protection in 2016. Handcrafts, which have been transferred for generations as cultural teaching of the local people in mountainous areas, have played an important role in promoting the cultural tourism features of the area. Various projects have been developed by the Provincial Directorate of Culture and Tourism to improve rural areas in local development and conserve these cultures, and their cultural qualities have been taken under protection.

\subsubsection{Infrastructure Features in Mountain Area Limitations}

Roads are the most important infrastructure services that can be offered in mountain areas regarding access. The employment and income opportunities in mountain areas mostly develop largely through access to surrounding plains and coastal areas, especially through road connections, or daily/seasonal worker migration (Kohler, Huarni, Wiesmann and Kläy, 2004: 41). Furthermore, infrastructure services for accessibility to areas with potential that contain tourism values in mountain areas are improve their standards on a daily basis. Investments made for the villages within the mountainsides are coordinated by the Governorship of Giresun and various projects and infrastructure aspects such as construction, modification and renewal processes are implemented annually. The projects prepared under the Köydes project as of 2019 and the budget of the village service
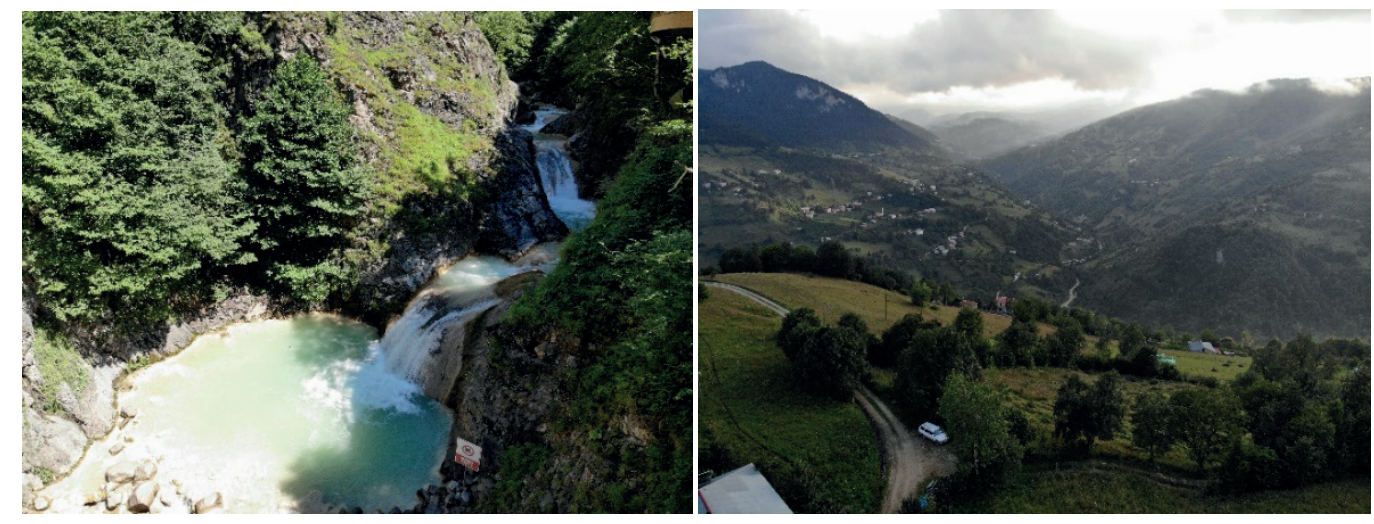

Figure 14. Natural Resource Richness Examples in Giresun Mountains. 
unions contributed a total of 814 infrastructure service access practices, including 672 village roads projects, 135 village freshwater projects and 7 wastewater projects, were on the agenda for the mountainous areas of Giresun. A total budget of 45.787.170 TL has been allocated for materializing these projects (Giresun Governorship, 2018). Internet usage and infrastructure lines, which are among the infrastructure features in the areas where energy systems and energy transmissions are completed, are widespread in all mountainous areas of Giresun. However, the infrastructure service insufficiencies regarding settlements in mountain areas were emphasized in the local public interviews.

\subsubsection{Health within Mountain Area Limitation}

The sustainability of health and healthy lifestyles in the mountainous areas where naturalness and health lifestyles are crystallized, international policies for the protection and development of these processes are among the main objectives in Agenda 21. Additional to the local people in the mountainous areas of Giresun, there are health centers established in rural settlements to meet seasonal workers' and tourist groups' health needs to respond to health problems in emergencies. Moreover, medical home services and home care service applications have also been implemented.

\subsubsection{Education within Mountain Area Limitation}

Educational processes, which is one of the least accessible subjects regarding mountainous areas development in the world has improvable aspects in line with national education policies, international education accessibility and non-governmental organizations (NGOs). Environment and development education is an important issue as well as besides basic education processes in Agenda 21 (Messerli and Bernbaum, 2004: 211). Turkey and Giresun for the dissemination of all education environments in general in 2003 initiated by UNICEF in collaboration with "Come on girls, off to school' campaign have been a big step for education in rural mountainous areas (Somuncu, 2006: 20). Bussed education, which takes place nationally in education services without discrimination in rural and urban settlements, is widespread in all mountainous areas of Giresun. Moreover, vocational courses are opened by Public Education Centers with the slogan of "Lifelong learning" for all ages. In 2018, a total of 2,160 training courses were offered throughout the province of Giresun, and 38,118 people participated in these courses. Yağlidere is the district with the highest number of courses within the mountainous area with 108 training courses and 2,111 participants. Following this district comes Dereli district with 74 courses and 1237 participants, Güce district with 51 courses and 914 participants, Çamoluk district with 21 courses and 203 participants, Çanakçı district with 21 courses and 178 participants, Alucra district with 17 courses and 381 participants, and Doğankent district with 12 courses and 212 participants, with a total of 402 courses and 5,393 participants (Provincial Directorate of National Education, 2018).

\subsubsection{Management and Mountain Policies within Mountain Areas Limitation}

Several countries participated in the United Nations world development summit in 1992, had consensus over 13th article of Agenda 21 which implies that mountain areas are fragile and vulnerable ecosystems with significant resources that need to be managed sustainably. The time-dependent endangered areas protected by the IUCN (International Union for Conservation of Nature) which takes the nature at its main principle but also considers the human impact, have been defined as a geographical area that is recognized and managed through legal and other effective means to ensure long-term protection of nature including integrated ecosystem services and cultural value (Dudley, 2008: 2). Mountain areas, managed as a geographical area, have a significant place in the environmental protection process which is a natural laboratory such as water, biological diversity, mining and tourism (Gönençgil, 2009: 119). Both international and national initiatives and non-governmental organizations such as IUCN, International Center for Integrated Mountain Development (ICIMOD), Food and Agriculture Organization of the United Nations (FAO) Mountain Partnership, Mountain Forum have developed various policies regarding mountainous area management and protection. Within the scope of these policies implemented by provincial directorate of national parks and nature conservation, mountainous and sensitive areas have been determined in this study focusing on Giresun, Turkey. These areas include Eğribel-Kurtbeli prospective national park area, Ağaçbaşı nature park, Koçkayası nature park, Kuzalan waterfall nature park, Yedideğirmenler cave and nature park, Köroğlu nature park, Şebinkarahisar waterfall prospective nature park area, Gölyanı Plateau and Aymaç prospective nature parks. Moreover, Karagöl Mountain prospective natural monument field, Şahinkayası prospective natural monument field, monumental tree prospective conservation areas, and hunting grounds for the control and protection of wildlife and fauna features such as Ambardağ 1 , Bicik, Bulancak, Paşakonağı official hunting grounds and prospective village wildlife development areas such as Şebinkarahisar, Arslanşah, Dereköy, Uğurca designated to 
protect and maintain the mountain areas in this area. Development and action plans for the protected areas and prospective conservation sites within the mountain area relimitations have been prepared by local administrations and the Directorate of Nature Conservation and National Parks.

\section{CONCLUSION}

The socio-economic qualities of the mountainous areas are considered important for the sustainability in these areas. Sustainable development in the mountainous areas in Giresun was examined and the relimitation of this area was analyzed on the basis of 11 criteria including socio-economic characteristics with a national-scale evaluation proposal.

Socio-economic approach regarding the mountain areas analysis was performed with regards to the substantial criteria that are considered effective in human development, related to altitude and topographic relimitation models, where the natural environment integrity is protected. The first stage of the study was performed to determine the physical limits of mountain areas to determine the guiding features regarding planning and scientific contribution. Thus, the determination of physical limits that depend on national and international relimitation criteria, Geographical Information Systems, altitude and topography was performed previously in several studies Kapos et al., (2000); Blyth, (2002); Meybeck et al., (2001); Sayre, Frye, Karagulle, Krauer, and Breyer at al., (2018), Price at al., (2018); ESPON, (2012); Price and Balsiger, (2015). However, the implementation of these relimitation studies in the mountain areas in Giresun was enabled by mountain area and impact zone determination studies and Geographical Information Systems (Dal and Gönençgil, 2018; Erol, 1992; Keçer, 1993). The determination of impact zones and mountain areas in Giresun mountains enabled the formulation of suitable conditions regarding the specification of their socio-economic characteristics. Studies emphasizing the importance of the socio-economic characteristics of mountain areas (European Commission, 2004); (Warren, 2002); (Price, Jansky and Iatsenia, 20049; (Zaman 2017); (Koday et al. 2017); (Kaymaz et al. 2017); (Li et al. 2016); (Kohler, Hurni, Wiesmann and Kläy, 2004); (Messerli and Bernbaum, 2004); (Messerli, 2012; Gönençgil, 2009); (Dudley, 2008); (IUCN n.d, ICIMOD n.d, Mountain Partnership n.d, Mountain Forum n.d) and Brundtland and Agenda 21 reports containing pivotal sustainability policies for these areas were utilized to formulate socio-economic analysis criteria. The classification of the socio-economic characteristics that flourish under natural environmental conditions and their impact into 11 criteria based on the prospective relimitations to different mountain ecosystems. These criteria are exemplified with mountainous area applications in Giresun province at a national level. The criteria reveal numerous advantages focused on the national and regional mountainous area relimitation approach. First, introducing the human factor in mountain area relimitations with physical integrity. Second, creating resources of humanenvironment interaction in mountainous areas that vary by time and place and for human-made applications within the mountain area limits. Third, propounding the assertion that mountain area limitations are not only dependent on the elevation and topography conditions, but also on the people who fundamentally influence these areas, with regards to these characteristics, have a significant role in these areas development and sustainability. Socio-economic characteristics that will be included in the mountain area limitations and based on humans, will take complementary roles in better understanding of mountain area limitations and in producing sustainable policies in these areas.

Peer-review: Externally peer-reviewed.

Author Contributions: Mapping- Y.K.; Methodology- Y.K.; Writing and visualization processes- Y.K.; Verification- S.K.; Examination- S.K.; Text editing- S.K. Conflict of Interest: The authors have no conflict of interest to declare. Grant Support: The authors declared that this study has received no financial support.

Hakem Değerlendirmesi: Dış bağımsız.

Author Contributions: Haritalama- Y.K.; Metedoloji- Y.K.; Yazım ve görselleştirme- Y.K.; Doğrulama- S.K.; İnceleme- S.K.; Metin düzenleme- S.K.

Çıkar Çatışması: Yazarlar çıkar çatışması bildirmemiştir.

Finansal Destek: Yazarlar bu çalışma için finansal destek almadığını beyan etmiştir.

\section{REFERENCES/KAYNAKÇA}

Akten, S., and Gül, A. (2014). Korunan Doğal Alanlarda Ziyaretçilerin Olası Etki Düzeyleri Önlem Ve Standartların Belirlenmesi (Gölcük Tabiat Parkı Örneği). Türkiye Ormancllk Dergisi, 15(2), 130-139.

Bayar, R., and Karabacak, K. (2020). Determination of human impact on land cover: The case of Ankara Province. Cografya Dergisi. Advance online publication. https://doi.org/10.26650/JGEOG2019-0043

Bekdemir, Ü., and Sezer, İ. (2016). Giresun İlinin Turizm Potansiyeli. Ankara: Nobel Bilimsel Eserler, Nobel Yayincilı.

Birinci, S. Kaymaz, C..K. and Camc1, A. (2017). Harran County Seat and Traditional Dome Residencies in Terms of Culture Tourism (Şanliurfa)", Turkish Studies-International Periodical for the Languages, Literature and History of Turkish or Turkic, 12(3), 93-118. http://dx.doi.org/10.7827/TurkishStudies.11289

Blyth, S. (2002). Mountain Watch: Environmental Change Sustainable Developmental in Mountains (No. 12). UNEP/Earthprint.

Botkin, J. W., Elmandjra, M., and Malitza, M. (1979). No Limits to Learning: Bridging the Human Gap: The Report to The Club of Rome. 
Dal, N., and Gönençgil, B. (2018). Türkiye'de Dağ ve Dağlık Alan Sınırlandırması için Bir Yaklaşım, TÜCAUM 30. Yll Uluslararası Coğrafya Sempozyumu, Bildiriler Kitabı, 907-913.

Dax, T. (2005). The redefinition of Europe's Less Favoured Areas. 3rd Annual Conference - Rural Development in Europe Funding European Rural Development in 2007-2013, 15-16 November 2005, London

Debarbieux, B., Price, M. F., and Balsiger, J. (2015). The institutionalization of mountain regions in Europe. Regional Studies, 49(7), 1193-1207.

Elibüyük, M., and Y1lmaz, E. (2010). Türkiye'nin Coğrafi Bölge ve Bölümlerine Göre Yükselti Basamakları ve Eğim Grupları (Altitude Steps and Slope Groups of Turkey in Comparison with Geographical Regions and Sub-Regions). Coğrafi Bilimler Dergisi/Turkish Journal of Geographical Sciences, 8(1), 27-55.

Erol, O. (1992). 1/1.000.000 scale Geomorphological map of Turkey. Ankara: MTA.

Espon (The European Observation Network for Territorial Development and Cohesion) and University of Geneva (2012). Geographical Specificities and Development Potentials in Europe: Final Scientific Report.

European Commission (2004). Mountain Areas in Europe: Analysis of Mountain Areas in EU member States, Acceding and other European Countries. Nordregio Report 2004: 1, Report to the Directorate-General for Regional Development, European Commission. Stockholm: Nordregio.

Fisunoğlu, M. (1997). Sürdürülebilir Kalkınma ve Ekonomi. Sürdürülebilir Kalkınmanın Uygulanması Tartışma Toplantısı 11-12 Aralık 1997, Ankara: Türkiye Çevre Vakfı Yayın, (126), 13-26.

Funnell, D. C. and Price, M. F. (2003). Mountain geography: A review. Geographical Journal, 169(3), 183-190.

Giresun İli Doğa Turizmi Master Planı (2013-2023). (2013). T.C. Orman ve Su İşleri Bakanlığı 12. Bölge Müdürlüğü Giresun Şube Müdürlüğü. Giresun.

Giresun Provincial Directorate of Agriculture and Forestry, 2018.

Giresun Provincial Directorate of Agriculture and Forestry, 2019.

Godde, P. M., Price, M. F. and Zimmermann, F. M. (Ed.). (2000). Tourism and Development in Mountain Regions. USA: Cabi Publishing

Gönençgil B. (1999). "Dağlık Alanların Sürdürülebilir Kullanımı İçin Dağ Alanları Yönetimi (DAY) ve Planlaması”, Türkiye 'de Çevre Kirlenmesi Öncelikleri Sempozyumu III, 18-19 Kasim 1999, Kocaeli

Gönençgil, B. (2009). Küresel Degredasyon Sürecinde Dağlar ve Dă̆ Alanları Yönetimi. İstanbul: Çantay Kitabevi.

Gürgen, G. (1997). Şebinkarahisar-Alucra Çevresinde Volkanik Şekiller. Ankara Üniversitesi Türkiye Coğrafyası Araştırma ve Uygulama Merkezi Dergisi, 6, 149-161.

Hoşgören, M. Y. (2011). Jeomorfoloji Terimleri Sözlüğ̈̈. İstanbul: Çantay Yayınevi.

Huddleston, B., Ataman, E., and Fe d'Ostiani, L. (2003). Towards a GIS-based Analysis of Mountain Environments and Populations. Environment and Natural Resources Working Paper 10. Rome: Food and Agricultural Organization of the United Nations.
Hulse, J. H. (2007). Sustainable Development at Risk: Ignoring the Past. International Development Research Centre, Cambridge University Press. India

Jia, Y., Tang, X., and Liu, W. (2020). Spatial-Temporal Evolution and Correlation Analysis of Ecosystem Service Value and Landscape Ecological Risk in Wuhu City. Sustainability, 12(7), 2803.

Kang, S., Lee, S. R., and Cho, S. E. (2020). Slope Stability Analysis of Unsaturated Soil Slopes Based on the Site-Specific Characteristics: A Case Study of Hwangryeong Mountain, Busan, Korea. Sustainability, 12(7), 2839.

Kapos, V., Rhind, J., Edwards, M., Price, M. F., and Ravilious, C. (2000). Developing A Map of The World's Mountain Forests. Forests in Sustainable Mountain Development: A State of Knowledge Report For 2000. Task Force on Forests in Sustainable Mountain Development, 4-19.

Keçer, M. (1993). 1 / 25.000 Scale Geomorphological Map of Giresun Province

Koday, S., Kaymaz, H., and Kaya, G. (2018). Kuzalan Tabiat Parki'nin Doğa Turizm Potansiyeli (Dereli-Giresun). Marmara Coğrafya Dergisi, 37, 124-143.

Koday, S., Koday, Z. and Kizılkan, Y. (2017). Siirt Ilinde Bir Mesken Kültürü: Cas Evleri. Atatürk Üniversitesi Sosyal Bilimler Enstitüsü Dergisi, 21(4), 1369-1385.

Kohler, T., Hurni, H., Wiesmann, U., and Kläy, A. (2004). Mountain infrastructure: access, communication, and energy. in Martin F. Price, Libor F. Jansky, and Andrei A. Iatsenia Key Issues for Mountain Areas (pp. 38-62). New York: United Nations University Press.

Kohler, T., Pratt, J., Debarbieux. B., Balsiger, J., Rudaz G., Maselli D., (eds) 2012. From Rio 1992 to Rio 2012 and beyond. Final Draft for Rio 2012. Sustainable Mountain Development, Green Economy and Institutions. Swiss Agency for Development and Cooperation (SDC); Centre for Development and Environment (CDE) University of Bern. Körner, C. (2003). Alpine Plant Life: Functional Plant Ecology of High Mountain Ecosystems. 2nd ed. Berlin: Springer.

Li, J. T., Liu, Y. S., and Yang, Y. Y. (2018). Land use change and effect analysis of tideland reclamation in Hangzhou Bay. Journal of Mountain Science, 15(2), 394-405.

Li, Y. J., Yu, H., Chen, T., Hu, J., and Cui, H. Y. (2016). Livelihood changes and evolution of upland ethnic communities driven by tourism: a case study in Guizhou Province, southwest China. Journal of Mountain Science, 13(7), 1313-1332. https://doi.org/10.1007/ s11629-015-3631-6

Löve, D. (1970). Subarctic and subalpine: Where and what?. Arctic and Alpine Research, 2, 63-73.

Meadows, D. H., Meadows, D. H., Randers, J., and Behrens III, W. W. (1972). The Limits to Growth: A Report To The Club of Rome, 1-9.

Messerli, B. (2012). Global Change and The World's Mountains. Mountain Research and Development, 32(1), 55-63.

Messerli, B., and Besubaum, E. (2004). The role of culture, education and science for sustainable mountain development,n Martin F. Price, Libor F. Jansky \& Andrei A. Iatsenia (Eds.) Key Issues for Mountain Areas (pp. 210-234). New York: United Nations University Press 
Meybeck, M., Green, P., and Vörösmarty, C. (2001). A New Typology for Mountains and Other Relief Classes. Mountain Research and Development, 21(1), 34-46.

Mountain Agenda. (2002). Mountains of the World. Sustainable Development in Mountain Areas, The Need for Adequate Policies and Instruments. Switzerland: Centre for Development and Environment, University of Berne.

Peattie, R. (1936). Mountain Geography: A Critique and Field Study. Harvard, Cambridge MA.

Peng, J., Hu, X., Qiu, S., Meersmans, J., and Liu, Y. (2019). Multifunctional landscapes identification and associated development zoning in mountainous area. Science of The Total Environment, 660, 765 775.

Planhol, X. D., and Bilgin, T. (1961). Karagöl Kütlesi Üzerinde Pleistosen ve Aktüel Glasiyasyon ile Periglasyal Topoğrafya Şekilleri. İst. Üniv. Coğ. Enst. Der, 6(12), 127-146.

Price M.F., and Butt, N. (2000). Forests in Sustainable Mountain Development: A Report for 2000. Wallingford: CAB International

Price M.F., Arnesen T., Gløersen E., and Metzger, M. J. (2018). Mapping mountain areas: learning from Global, European and Norwegian perspectives. Journal of Mountain Science, 16(1). https://doi. org/10.1007/s11629-018-4916-3

Price, M. (2004). Introduction: Sustainable Mountain Development from Rio To Bishkek And Beyond. Key Issues For Mountain Areas, United Nations University, New York, 1-17.

Price, M. F. (2013). Mountain Geography: Physical and Human Dimensions. University of California Press.

Price, M. F., and Kohler T. (2013). Sustainable Mountain Development in Alton C. Byers, Donald A. Friend, Thomas Kohler \& Larry W. Price. (Eds.) Mountain Geography: Physical and Human Dimensions. (pp. 333-363). Univ of California Press.

Provincial Directorate of National Education, 2018

Provincial Directorate of Nature Conservation and National Parks

Rodríguez-Rodríguez, D., and Bomhard, B. (2012). Mapping direct human influence on the world's mountain areas. Mountain Research and Development, 32(2), 197-202.

Sati, V. P. (2005). Natural resource conditions and economic development in the Uttaranchal Himalaya, India. Journal of Mountain Science, 2(4), 336-350. https://doi.org/10.1007/BF02918407

Sayre, R., Frye, C., Karagulle, D., Krauer, J., Breyer, S., Aniello, P., ... and VanSistine, D. P. (2018). A new high-resolution map of world mountains and an online tool for visualizing and comparing characterizations of global mountain distributions. Mountain Research and Development, 38(3), 240-249.

Soffer, A. (1982). Mountain Geography: A New Approach. Mountain Research and Development, 2(4), 391-398.

Somuncu, M. (2002). "2002 Dünya Dağlar Y1lında Dünyada ve Türkiye'de Dağ Turizmi”. TC Turizm Bakanlığı II. Turizm Şurası Bildirileri, I. Cilt, 185-192.
Somuncu, M. (2006). Achieving universal primary education in mountains. Mountain Research and Development, 26(1), 20-23.

UNCED (1972). Declaration of the United Nations conference on the human environment (Stockholm Declaration) A/CONF.48/14/ REV.1 - Report of the United Nations Conference on Human Environment. Stockholm

UNCED. (1992). Agenda 21. UN Doc. A/CONF. 151/26 (Vol. I-II-II), 13 August. Washington D.C.: United Nations.

Uzun, A. (2014). Sürdürülebilir Kalkınma Kapsamında Madra Dağı'nın Doğal ve Beşerî Kaynaklarının Değerlendirilmesi. (Yayınlanmamış Doktora Tezi). Ankara: Ankara Üniversitesi.

Uzun, A., and Somuncu, M. (2013). Madra Dağ1 ve Çevresinin Arazi Örtüsü/Kullanımındaki Zamansal Değișimin Uzaktan Algılama Yöntemi ile Değerlendirilmesi. Balıkesir Üniversitesi Sosyal Bilimler Enstitüsü Dergisi, 16(30), 1-21.

Uzun, A., Zeybek, H., and Demirağ, İ. (2012). Sariçiçek Dağı'nda Dolin Topoğrafyası (Giresun/ Türkiye), UJES 2012, III. Ulusal Jeomorfoloji Sempozyumu, Hatay.

Uzun, A., Zeybek, H., and Hatipoğlu, İ. K. (2012). Bazaltik Aglomeralar Üzerinde Tor Oluşumu, Giresun, UJES 2012, III. Ulusal Jeomorfoloji Sempozyumu, Hatay.

Veith, C., and Shaw, J. (2011). Why Invest in Sustainable Mountain Development? Rome: Fao Publishg.

Warren, P. (2002). Livelihoods Diversification and Enterprise Development. An Initial Exploration of Concepts and Issues. Livelihood Support Program (LSP) Working Paper, Italy.

WCED (1987). Our Common Future, Brundtland Report of the World Commission on Environment and Development, Published as Annex to General Assembly document A/42/427.

Wymann von Dach, S., Bachmann, F., Borsdorf, A., Kohler, T., Jurek, M. and Sharma, E., eds. (2016). Investing in Sustainable Mountain Development: Opportunities, Resources and Benefits. Centre for Development and Environment (CDE) Switzerland: Bern Open Publishing.

Zaman, M. (2017). Türkiye’de Kırsal Meskenler ve Coğrafi Dağılışları. Atatürk Üniversitesi Sosyal Bilimler Enstitüsü Dergisi, 21(3), 911935.

International Union for Conservation of Nature. (No date). About Protect Areas Retrieved form https://www.iucn.org/ Last update: 28.04.2021

International Center for Integrated Mountain Development. (No date) About Mountain Development Retrieved form https://www.icimod. org/ Last update: 28.04.2021

Mountain Partnership (No date). About Mountain Development Retrieved form http://www.fao.org/mountain-partnership/en/ Last update: 28.04 .2021

Mountain Forum (No date). About Mountain Conservation and Development Retrieved form http://www.fao.org/3/w9300e/w9300e04. htm Last update: 28.04.2021 